\title{
Analisis Persepsi Pondok Pesantren Terhadap Lembaga Keuangan Syariah (Studi Kasus Pada Pondok Pesantren Zainul Hasan Genggong Probolinggo)
}

\author{
Mustofa $^{1}$, Zainollah ${ }^{2}$ \\ Sekolah Tinggi Ilmu Ekonomi Mandala ${ }^{1,2}$
}

\begin{abstract}
The existence of sharia financial institutions in the districts Probolinggo became the object of interest primarily among boarding school. Islamic financial institutions conducted by the banking community has created a separate perception for the community of pesantren or santri. The activities of Islamic financial institutions be interesting people, but the existence of the financial institution of sharia cause different perceptions. Some assume that Islamic financial institutions are no different from conventional financial institutions. The research method used is qualitative descriptive analysis. Collected by observation technique and interview with structured question supported by closed questionnaire to informant to know opinion perception of the existence of Islamic financial institutions, by using Snowball Sampling method. From the discussion of the above problems, it can be concluded that the perception of the santri community at the Genggong cottage, both those who are customers and those who are not Islamic bank customers, in terms of cultural, social, personal and psychological approaches, is positive towards Islamic banks. The differences that exist in the santri community of customers and non customers are on their attitude or choice to choose or not to choose sharia bank.
\end{abstract}

Keywords: Islamic finance, santri, pesantren

\section{PENDAHULUAN}

\section{Latar Belakang}

Semakin berkembangnya sektor perbankan syariah yang ditandai dengan munculnya UU No, 7 tahun 1992 yang kemudian di amandemen menjadi UU No.10 tahun 1998 dan terakhir diterbitkan UU No. 21 tahun 2008 tentang

Corresponding Author:

Email : mustofa@stie-mandala.ac.id 
perbankan syariah. Dalam Undang-Undang Republik Indonesia No. 21 tahun 2008 tentang Perbankan Syariah tersebut dinyatakan bahwa Bank adalah badan usaha yang menghimpun dana dari masyarakat dalam bentuk Simpanan dan menyalurkannya kepada masyarakat dalam bentuk kredit dan atau bentuk lainnya dalam rangka meningkatkan taraf hidup rakyat.

Bank syariah memiliki peran yang cukup penting sebagai ujung tombak dalam menggerakan sektor riil melalui pembiayaan yang pada umumnya bersifat jangka panjang, sehingga tujuan dari ekonomi Islam dapat tercapai. Oleh karena itu, bank syariah harus mampu mengelola titipan dana dari masyarakat yang mayoritas berjangka pendek secara hati-hati guna mencegah terjadinya maturity mismatch. Untuk itu dibutuhkan suatu sarana yang dapat membantu bank syariah dalam mengelola likuiditas hariannya secara efektif dan efisien. Pengelolaan likuiditas yang tidak efektif dan tidak efisien akan mengganggu kinerja bank umum syariah (BUS) dan unit usaha syariah (UUS) serta dapat berdampak pada turunnya kepercayaan masyarakat terhadap perbankan syariah yang pada akhirnya akan membahayakan sistem perbankan dan sistem keuangan secara keseluruhan.

Kabupaten Probolinggo masyarakatnya sangat religius dan ada salah satu pesantren yang merupakan salah satu yang terbesar di Indonesia .Pondok pesantren Zainul Hasan Genggong atau lebih dikenal dengan sebutan pondok Genggong adalah yayasan pendidikan pesantren yang dibangun pada tahun 1839 oleh Almarhum KH. Zainul Abidin dari keturunan Maghribi, Maroko Afrika. Pesantren Zainul Hasan Genggong kini memiliki sekitar 20.000 santri dan berlokasi di Desa KarangBong, Kecamatan Pajarakan, Kabupaten Probolinggo ,JawaTimur. (id.wikipedia.org/wiki/Pesantren_Zainul_Hasan_Genggong)

Untuk memperoleh gambaran yang komprehensif tentang persepsi santri terhadap lembaga keuangan syariah di pondok pesanten Zainul Hasan Genggong Probolinggo, maka perumusan masalah adalah sebagai 1). Bagaimana karakteristik demografis, sosial (social capital), ekonomi dan budaya masyarakat santri khususnya di pondok pesanten Zainul Hasan Genggong Probolinggo; 2). Bagaimana hubungan diantara kelompok pemangku kepentingan (StakeHolders) yaitu kalangan pesantren atau santri, lembaga 
pemerintah, lembaga swasta, dan lembaga masyarakat sehubungan dengan keberadaan lembaga keuangan syariah sekaligus pemetaan masyarakat?; 3).Bagaimana pendapat kalangan pesantren atau santri tentang lembaga keuangan syariah yang ada saat ini?.

\section{TINJAUAN PUSTAKA}

Suatu upaya untuk meningkatkan perekonomian dan kesejahteraan masyarakat, pemerintah memiliki beberapa pilihan diantaranya mendorong investasi swasta, meningkatkan pengeluaran untuk sektor pendidikan dan kesehatan guna memajukan modal manusia (human capital), menjaga lingkungan hidup, atau menambah stok infrastruktur. Salah satu alternatif yang menjadi perhatian setiap negara terlebih bagi negara - negara berkembang umumnya adalah penambahan infrastruktur dan pengembangan industri dalam artian luas guna mendorong pertumbuhan ekonominya.

Schmid menunjukkan bahwa stok kebutuhan barang publik tersebut di sebuah negara bervariasi terhadap jumlah penduduk, PDB per kapita, biaya pengadaan dan geografi. Misalnya Hongkong dan Singapura dengan tingkat kepadatan penduduk yang tinggi mempunyai kapasitas jalan/kapita yang tidak terlalu besar (Schmid, 2005: 6).

\section{Dimensi Teori Eksternalitas}

Berbagai pendapat mengemukakan teorinya tentang pengertian eksternalitas. Pendapat Rosen (2008:9) menyatakan bahwa eksternalitas terjadiketika aktivitas suatu satu kesatuan mempengaruhi kesejahteraan kesatuan yang lain yang terjadi di luar mekanisme pasar (non market mechanism). Tidak seperti pengaruh yang ditransmisikan melalui mekanisme harga pasar, eksternalitas dapat mempengaruhi efisiensi ekonomi. Dalam hal ini eksternalitas merupakan konsekuensi dari ketidak mampuan seseorang untuk membuat suatu property right.

Fisher (2006:11) mengatakan bahwa eksternalitas terjadi bila satu aktivitas pelaku ekonomi (baik produksi maupun konsumsi) mempengaruhi kesejahteraan ketika aktivitas suatu satu kesatuan mempengaruhi kesejahteraan kesatuan yang lain yang terjadi di luar mekanisme pasar (non market mechanism). Tidak seperti pengaruh yang ditransmisikan melalui mekanisme harga pasar, eksternalitas dapat 
mempengaruhi efisiensi ekonomi. Dalam hal ini eksternalitas merupakan konsekuensi dari ketidakmampuan seseorang untuk membuat suatuproperty right. Fisher (2006:11) mengatakan bahwa eksternalitas terjadi bila satuaktivitas pelaku ekonomi (baik produksi maupun konsumsi) mempengaruhi kesejahteraan pelaku ekonomi lain dan peristiwa yang ada terjadi di luar mekanisme pasar. Sehingga ketika terjadi eksternalitas, maka private choices oleh konsumen dan produsen dalam private markets umumnya tidak menghasilkan sesuatu yang secara ekonomi efisien.

\section{Modal Sosial dan Kepercayaan}

Modal Sosial (Social Capital) memiliki pengertian sebagai modal yang dimiliki oleh masyarakat dalam pemberdayaan masyarakat. Modal ini merupakan perpaduan antara sesuatu yang bersifat material dan non material. Material mempunyai makna tentang kepemilikan berkaitan dengan aset-aset finansial yang dimiliki, sedangkan non material merupakan modal tidak berwujud (intangible) dan adanya kepercayaan (trust) dan sistim kebersamaan (gathering system) dalam suatu masyarakat.

\section{Budaya Masyarakat dan Pengembangan Industri}

Perilaku masyarakat (customerbehavior) adalah proses pengambilan keputusan dan aktivitas fisik yang dilakukan oleh seseorang dalam menilai, mempunyai persepsi terhadap lingkungan disekitarnya. Indikatordari Perilaku Masyarakat ini adalah penentuan keputusan/masalah (problem recognition), pencarian informasi (information search), penelitan alternatif (evaluation of alternatives), keputusan membeli (purchase decision), dan perilaku pasca pembelian (post purchace behavior).

\section{Persepsi dan Perilaku}

Persepsi dan perilaku merupakan dua aspek yang mempengaruhi gambaran diri seseorang. Persepsi merupakan pandangan atau konsep yang dimiliki seseorang mengenai sesuatu hal, sedangkan perilaku adalah tindakan/ aspek dinamis yang muncul dari persepsi tersebut. Menurut Rahmat dalam Azwar (2005:19) persepsi merupakan pengalaman tentang obyek, peristiwa atau hubungan yang diperoleh dengan mengumpulkan informasi dan menafsirkan 
pesan pada stimulasi indrawi sehingga manusia memperoleh pengetahuan baru.

Penelitian Terdahulu

Fachruddin Fahmy Siregar (2009), Menulis tentang Persepsi Masyarakat Terhadap Pembukaan Pertambangan Emas di Hutan Batang Toru Kabupaten Tapanuli Selatan.

Muhammad Lukman Hakim (2008), dalam penelitiannya menganalisis tentang Dampak ekologi, ekonomi, sosial dan politik dari kebijakan pertambangan di hutan lindung (studi kasus pertambangan emas di hutan lindung Tumpang Pitu Kabupaten Banyuwangi

\section{Kerangka Pemikiran}

Untuk mempermudah pemahaman pada rencana tindakan penelitian yang dilakukan, maka diberikan gambaran dalam diagram kerangka pemikiran penelitian, sehinga diharapkan dengan gambar kerangka pemikiran ini akan mempermudah pemahaman pada alur berfikir pemikiran. Adapun gambar kerangka pemikiran tersebut adalah sebagai berikut

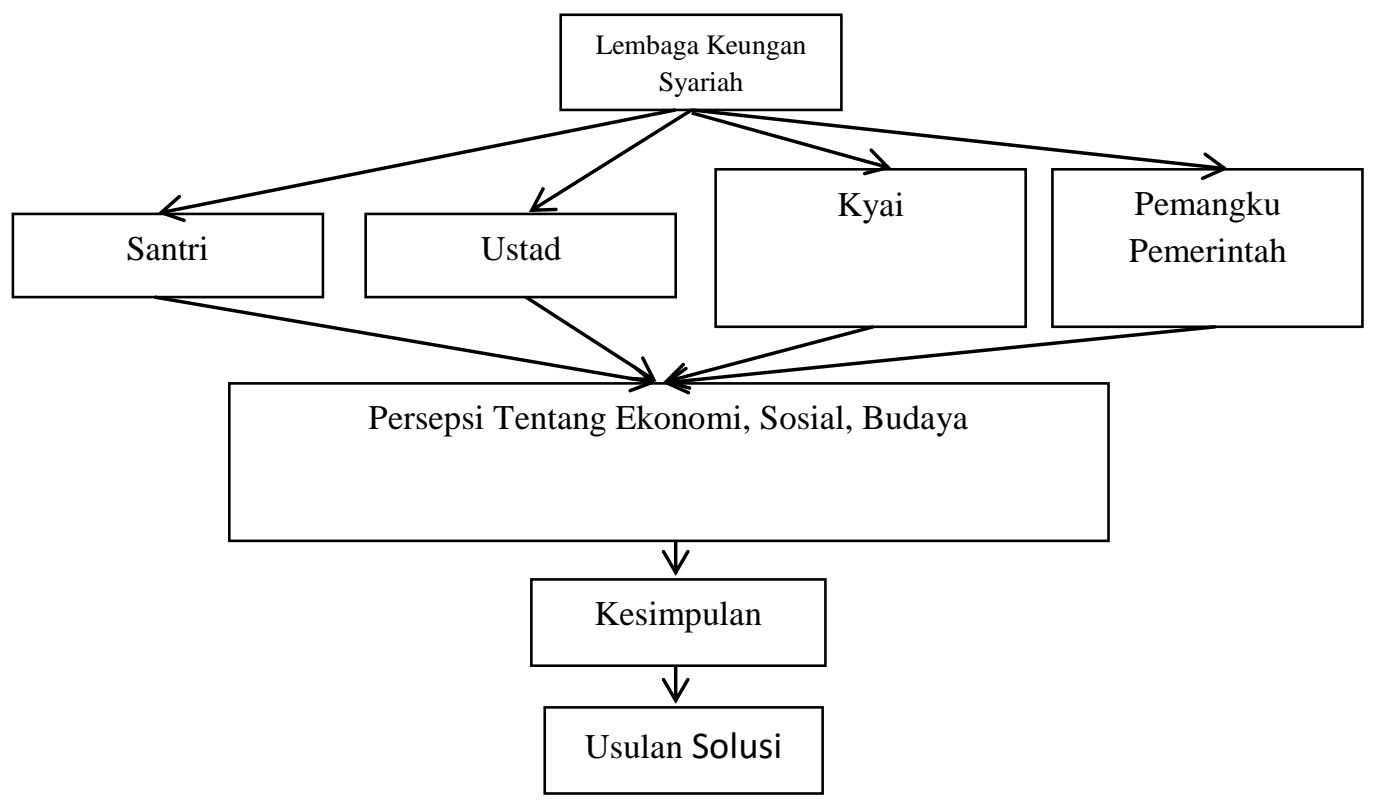

Gambar 2.1 Kerangka Pemikiran 


\section{METODOLOGI PENELITIAN}

\section{Jenis Penelitian}

Studi ini merupakan penelitian evaluasi kualitatif bersifat persepsi, dimana peneliti berusaha memahami makna kejadian dan interaksi yang terjadi pada orang-orang di dalam satu komunitas dalam situasi tertentu. Perspektif yang digunakan adalah perspektif verstehen, yakni pemahaman menurut tafsiran atas interaksi orang-orang.

Sebagaimana telah disampaikan di bab sebelumnya bahwa dalam ranah studi sosial kemasyarakatan, studi ini pada dasarnya dapat digolongkan sebagai suatu bentuk kegiatan evaluasi terhadap persepsi komunitas masyarakat terhadap kegiatan tentang persepsi santri terhadap lembaga keuangan syariah di pondok pesanten Zainul Hasan Genggong Probolinggo. Komunitas disini berarti stakeholders dan jejaringnya di pesanten Zainul Hasan Genggong Probolinggo, artinya studi ini juga merupakan kajian stakeholder smapping. Hal ini terkait dengan kebutuhan untuk menjawab tujuan bahwa studi tidak hanya memberikan deskripsi mengenai proses interaksi timbal balik antara lembaga keuangan syariah terhadap lingkungan strategisnya, yakni masyarakat dan stakeholder baik di kawasan pesanten Zainul Hasan Genggong Probolinggo. Studi juga meminta peneliti dapat menjawab "seberapa jauh" dan bagaimana perubahan persepsi serta pola patron-klein masyarakat di sekitar kawasan terhadap keberadaan operasi lembaga keuangan syariah dalam berbagai konteks. Artinya konsultan perlu melakukan analisis persepsi, pola patron-klien serta analisis kebutuhan masyarakat di lingkungan kawasan pesanten Zainul Hasan Genggong Probolinggo.

Unit analisis dalam kajian ini adalah persepsi santri dan pemangku kepentingan pada masyarakat di sekitar lokasi pesanten Zainul Hasan Genggong Probolinggo. Dalam hal ini adalah snatri dan pelaku kepentingan pada masyarakat di pesanten Zainul Hasan Genggong Probolinggo. Berdasarkan unit analisis tersebut yang menjadi populasi adalah seluruh santri dan Seluruh pemangku kepentingan di pesanten Zainul Hasan Genggong Probolinggo. 


\section{Lokasi Penelitian}

Penelitian ini mengambil lokasi di pesanten Zainul Hasan Genggong Probolinggo menggunakan teknik purposive random sampling. Lokasi yang dipilih tersebut diharapkan dapat mewakili karakteristik sosial ekonomi masyarakat yang berkaitan langsung atau tidak langsung dengan kegiatan lembaga keuangan syariah.

\section{Populasi dan Sampel}

Pengambilan sampel melalui dua tahap yakni yakni sampel wilayah dan Sampel santri serta pemangku kepentingan (Stakeholders). Di tataran sampel santri dan stakeholders dilakukan secara "snowball sampling" atau metode bola salju yang digulirkan dari atas bukit, dimana ibarat informasi saat digulirkan masih sedikit (kecil), kemudian saat digulirkan ke bawah akan membesar, demikian informasi yang dibutuhkan dimulai dengan referensi "simpul" awal setelah simpul awal tersebut selesai, lalu minta referensi simpul lanjutan yang bisa dihubungan dan dilakukan wawancara mendalam lagi hingga dirasa cukup, kemudian untuk simpul ketiga diambil berdasarkan referensi sebelumnya. Wawancara dihentikan hingga dirasa informasi cukup. Kemudian diambil simpul lain sebagai simpul awal pula, kemudian proses berulang.

Jenis dan Sumber Data

Sumber data penelitian ini tidak saja menggunakan satu sumber data lapangan atau data primer, tetapi juga menggunakan data sekunder. Menurut Marzuki (2000: 55), sumber data dapat dibedakan menjadi dua, yaitu:

\section{Data primer}

Data primer, yaitu data yang diperoleh langsung dari sumbernya. Data tersebut diperoleh dari para responden dalam penelitian ini. Untuk itu akan digunakan metode "snowballsampling" terkait dengan tujuan penelitian.

\section{Data sekunder}

Data sekunder, yaitu data yang bukan diusahakan sendiri oleh peneliti. Data tersebut diperoleh dari Data, Desa, Potensi Desa, Kabupaten Dalam Angka, Badan Pusat Statistik (BPS), Bank Indonesia (BI), perpustakaan, majalah, internet, artikel atau jurnal yang berhubungan dengan obyek penelitian. Data 
sekunder yang dibutuhkan adalah ekonomi, sosial budaya, politik atau hukum, dan teknologi.

Secara teoritis akademis, data yang diperlukan di dalam studi ini terdiri dari data primer dan sekunder, baik kualitatif maupun kuantitatif. Data primer yang diperlukan antara lain data tentang kondisi fisik lapangan (physical geography, demografis ,budaya, dan environment). Kawasan di sekitar kawasan pesanten Zainul Hasan Genggong Probolinggo.

Pesanten Zainul Hasan Genggong Probolinggo, kegiatan sosial ekonomi, serta hubungan antar lembaga di lapangan dan atau hubungan patron-klien dan patron-patron. Dalam kaitan dengan hal di atas, persepsi masyarakat santri terhadap keberadaan terhadap lembaga keunangan syariah, juga akan menjadi perhatian studi ini.

Data sekunder yang diperlukan antara lain berbagai jenis pustaka, seperti: Rencana Tata ruang wilayah, Pembangunan Jangka Panjang, dan Rencana Jangka Pendek Kabupaten Probolinggo khususnya kawasan pesanten Zainul Hasan Genggong Probolinggo, Kabupaten Probolinggo Dalam Angka, Laporan Tahunan dari Dinas-Dinas Daerah, laporan-laporan studi, serta buku-buku dan dokumen-dokumen yang berkaitan dengan kawasan disekitar pesanten Zainul Hasan Genggong Probolinggo.

\section{Teknik Pengumpulan Data}

Sementara itu, teknik pengumpulan data merupakan prosedur untuk memperoleh data-data yang diperlukan dalam penelitian. Teknik pengumpulan data dapat dilakukan dengan:

1. Observasi,yaitu teknik pengumpulan data dengan mengadakan pengamatan secara langsung terhadap obyek penelitian yang kemudian dilakukan penelitian secara sistematis;

2. Wawancara, yaitu teknik pengumpulan data dengan jalan tanya jawab sepihak yang dikerjakan secara sistematis dan berlandaskan pada tujuan penelitian;

3. Dokumentasi, yaitu teknik yang digunakan dengan cara peminjaman terhadap arsip-arsip perusahaan. Khususnya yang berkaitan dengan masalah-masalah yang diteliti; 
4. Studi pustaka, yaitu teknik pengumpulan data dengan melakukan studi literatur terhadap buku-buku yang relevan, surat kabar, majalah, dan tulisan-tulisan ilmiah.

Instrumen yang digunakan dalam penelitian ini berupa studi deskriptif melalui survey kepustakaan dan survey lapangan melalui kegiatan pengamatan mendalam dengan metode snowball sampling..

Wawancara yang dilakukan bersifat terbuka (open-ended questions).

Wawancara yang bersifat terbuka hanya digunakan untuk tahapan awal penelitian, yang ditujukan untuk menangkap gambaran umum kondisi sosial ekonomi santri. Wawancara dilakukan pada masyarakat (termasuk tokoh masyarakat) di desa sampel melalui metode snowballsampling. Metode ini bertujuan untuk memperoleh gambaran yang menyeluruh tentang karakteristik sosial ekonomi masyarakat, persepsi masyarakat terhadap persepsi santri mengenahi lembaga keuangan syariah. Wawancara juga dilakukan pada pemangku pengambil keputusan baik di level informal maupun formal baik di tingkat santri , ustad, pengurus hingga pengasuh kyai dan keluarganya dengan tujuan untuk menangkap persepsi terkait dengan keberadaan lembaga keuangan syariah.

\section{Teknik Pengolahan Data}

Data kualitatif merupakan sumber dari deskripsi yang luas dan berlandasan kokoh serta memuat penjelasan tentang proses-proses yang terjadi dalam lingkup setempat. Dengan data kualitatif kita dapat mengikuti dan memahami alur peristiwa secara kronologis, menilai sebab-sebab dalam lingkup pikiran orangorang setempat. Data mentah dan data kasar (catatan lapangan yang belum tersusun, pita rekaman hasil dikte, rekaman langsung) sebelum dianalisis.

\section{Analisis Data}

Menurut Miles\& Huberman (2002:305) analisis terdiri dari tiga alur kegiatan yang terjadi secara bersamaan yaitu:

A.Reduksi data

Adalah proses pemilihan, penyerderhanaan, pengabstrakan dan transformasi data "kasar" yang muncul dari catatan tertulis di lapangan. Pilihan peneliti tentang 
bagian data mana yang dikode, mana yang dibuang, pola-pola mana yang meringkas sejumlah bagian yang tersebar, cerita-cerita apa yang sedang berkembang.

\section{Penyajian data}

Penyajian sebagai sekumpulan informasi tersusun yang memberi kemungkinan adanya penarikan kesimpulan dan pengambilan tindakan. Dengan melihat penyajian-penyajian kita akan dapat memahami apa yang sedang terjadi dan apa yang harus dilakukan lebih jauh menganalisis atau mengambil tindakan berdasarkan atas pemahaman yang didapat dari penyajian-penyajian tersebut.

\section{Menarik kesimpulan/verifikasi}

Dari permulaan pengumpulan data seorang penganalisis kualitatif dimulai dari mencari arti benda-benda, mencatat keteraturan, pola-pola penjelasan, konfigurasikonfigurasi yang mungkin, alur sebab akibat dan proposisi. Penarikan kesimpulan hanyalah sebagian dari satu kegiatan dari konfigurasi yang utuh. Kesimpulan juga diverifikasi selama penelitian berlangsung. Untuk memberikan alur pemikiran serta gambaran yang lebih jelas tentang alur proses analisis data yang dilakukan adalah dengan skema yang tertuang pada gambar 3.1 sebagaimana gambar berikut

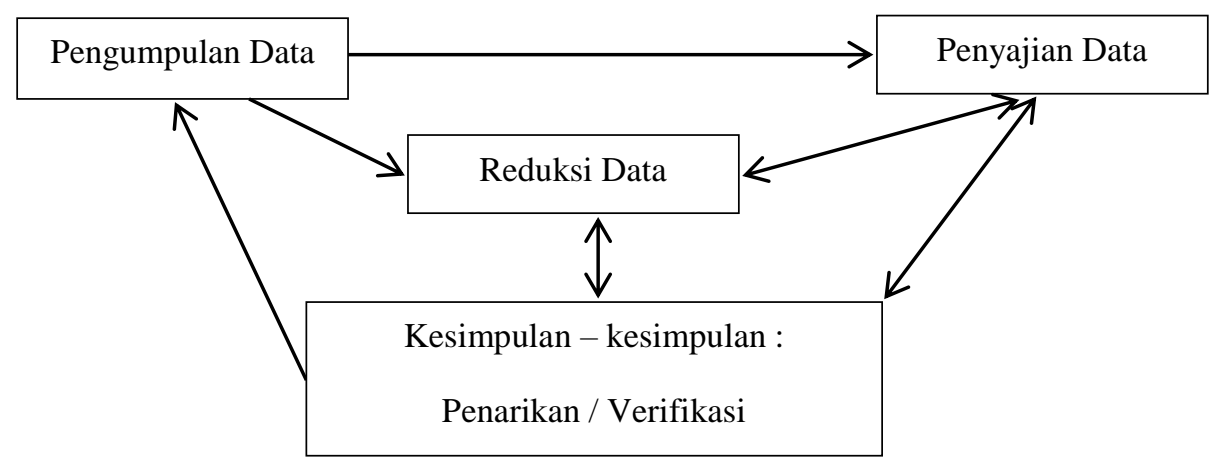

Gambar 3.1 Model Analisis Interaktif Miles \& Huberman

Tiga jenis kegiatan analisis dan kegiatan pengumpulan data data merupakan proses siklus interaktif. Peneliti bergerak diantara empat sumbu kumparan itu selama pengumpulan data, selanjutnya bergerak bolak-balik diantara kegiatan reduksi, penyajian dan penarikan kesimpulan/verifikasi. Hasil analisis 
akan dibahas dengan mempergunakan beberapa pendekatan, antara lain:

A. Pendekatan kelembagaan.

Hal ini dilakukan karena stakeholders atau pemangku kepentingan Kawasan di sekitar lokasi kawasan pesanten Zainul Hasan Genggong Probolinggo terdiri dari santri dan lembaga-lembaga di pesantren, dan lembaga masyarakat yang saling berhubungan satu sama lain.

B. Pendekatan perbandingan.

Halini dilakukan untuk dapat memperoleh gambaran yang jelas tentang situasi dan kondisi Kawasan kawasan pesanten Zainul Hasan Genggong Probolinggo cara membandingkan, misalnya, antara fenomena Lingkungan yang satu dengan fenomena lingkungan lainnya.

C. Pendekatan sebab akibat.

Hal ini dilakukan untuk mengetahui bahwa terjadinya sesuatu di Kawasan di Sekitar kawasan pesanten Zainul Hasan Genggong Probolinggo merupakan akibat dari sesuatu sebab tertentu, misalnya keberadaan lembaga keuangan syariah terhadap masyarakat khususnya secara sosial, ekonomi dan budaya, bahkan keberadaan pertanian ,pesisir dan nelayan.

D. Pencarian Alternatif Tindakan.

Hal ini dilakukan untuk mencari kemungkinanperbaikan perkonomian masyarakat setempat dengan melihat dan memberdayakan potensi wilayah sebagai solusi alternatif terhadap permasalahan yang terjadi dengan menggunakan Analisis SWOT (Strength; Weakness; Opportunity; Threath).

\section{HASIL DAN PEMBAHASAN}

Untuk memperoleh hasil penelitian yang jelas serta tidak menimbulkan kesalahan dalam pemahaman tentang obyek dari penelitian, maka diperlukan sebuah paparan secara jelas terhadap obyek penelitian. Maka untuk kepentingan tersebut dipaparkan uraian daerah penelitian, hal ini disebabkan suatu persepsi yang dimiliki masyarakat sebagai obyek penelitian tidak terbentuk begitu saja, akan tetapi sangat dipengaruhi oleh faktor-faktor lingkungan serta pengalaman hidup dari masyarakat sasaran penelitian. Adapun paparan uraian daerah 
penelitian adalah sebagaimana penjelasan berikut.

Lokasi penelitian dilakukan di pondok pesantern kabupaten Probolinggo provinsi Jawa Timur. Yaitu sebuah kawasan pesisir terletak di kabupaten Probolinggo yang posisinya berada pada wilayah Timur Utara kabupaten Probolinggo. Secara geografis terletak pada posisi 112'50' - 113'30' Bujur Timur (BT) dan 7'40'-8'10' Lintang Selatan (LS). Letaknya cukup dekat dengan ibukota Probolinggo yaitu kota Kraksaan sekitar $3 \mathrm{~km}$. Semenjak terjadi pemekaran wilayah dimana kota Probolinggo terpisah sendiri dari kabupaten, maka ibukota kabupaten di pindah ke kota Kraksaan. Adapun batas administratif wilayah kabupaten Probolinggo sebelah utara selat Madura, batas wilayah selatan kabupaten Lumajang dan kabupaten Malang, batas wilayah barat kabupaten Pasuruan, batas wilayah timur kabupaten Jember dan kabupaten Situbondo (wikipedia kab.Probolinggo).

Berdirinya Pesantren Zainul Hasan sejak awal pendiriannya dikenal dengan sebutan Pondok Pesantren Genggong yang didirikan oleh KH. Zainul Abidin pada tahun 1839 M / 1250 H. Yang terletak di desa Karangbong Kecamatan Pajarakan Kabupaten Probolinggo. Adapun motifasi pendiri Pesantren tersebut merupakan cita-cita mulia dan luhur yang didasarkan pada tanggung jawab secara keilmuan setelah melihat realitas masyarakat yang masih buta huruf dan masyarakatnya dikenal dengan awam yang sama sekali tidak mengenal ilmu pengetahuan agama secara perilaku kehidupan masyarakat cenderung berperilaku yang bertentangan dengan nilai-nilai agama seperti melakukan perbuatan dosa besar kepada Allah SWT, baik perbuatan syirik, zina, perilaku kekerasan sesamanya dengan cara merampas hak milik orang lain dan penganiayaan terhadap sesamanya serta perbuatan judi yang dilakukan oleh masyarakat setiap hari. Berangkat dari dasar pemikiran yang didasarkan pada realitas perilaku masyarakat tersebut, maka $\mathrm{KH}$. Zainul Abidin, dia keturunan maghrobi dan alumnus pesantren Sidoresmo Surabaya merasa terpanggil jiwanya untuk mengamalkan ilmu yang didapatnya kemudian dijadikan dasar berjuang dengan menebarkan ilmu pengetahuan agama baik berupa pengajian maupun di sampaikan melalui kelembagaan berupa institusi Pondok Pesantren. 


\section{Pondok Pesantren Genggong}

Dasar-dasar pengembangan Pesantren Zainul Hasan Genggong di arahkan pada pendidikan sesuai dengan kebutuhan zaman, akan tetapi pendidikan pesantren pada setiap satuan pendidikannya tetap memperkuat jati dirinya sebagai bagian dari Pesantren Salafiyah dengan berpedoman pada kaidah “ALMUHAAFADHATU'ALA QODIIMIS SHOLEH WAL AKHDU BIL JADIDIL ASHLAH Yang artinya "Mempertahankan metodologi yang lama dan mempergunakan metodologi yang baru yang lebih baik". Dasar tersebut di atas itulah yang dijadikan pedoman bagi pengembangan pendidikan Pesantren Zainul Hasan Genggong yang ditandai dengan dibukanya beberapa sekolah dan madrasah dengan mengunakan metodologi yang baru dalam konsep pembelajarannya yang dapat memperkuat jati diri lulusan pendidikan pesantren tetap berpegang teguh pada pada moralitas, budi pekerti yang luhur dan konsep penanaman ibadah sebagai bagian dari penuntasan belajar dan bagian dari jati dirinya.

\section{Persepsi Sistem Perbankan Syariah}

Persepsi yang muncul di mana hasil penelitian untuk permasalahan kedua menunjukkan bahwa responden masyarakat santri non nasabah bank syariah menggunakan lembaga keuangan lain dalam kegiatan pengelolaan keuangannya, diantaranya adalah bank konvensional, pegadaian, koperasi, dan BMT. Sementara itu, sebesar $46 \%$ dari 150 responden masyarakat santri yang menjadi nasabah bank syariah baik dari kelompok ulama, siswa santri, alumni santri maupun masyarakat sekitar pesantren selain menggunakan bank syariah ternyata juga memanfaatkan lembaga keuangan lain, untuk menyimpan, meminjam dan mengirim uang. Perbandingan prosentase antara masyarakat santri nasabah bank syariah yang hanya menggunakan bank syariah saja dalam mengelola keuangannya dengan masyarakat santri nasabah bank syariah yang juga menggunakan lembaga keuangan lain selain bank syariah.

Dari hasil pendekatan yang dilakukan kepada masyarakat terdapat sembilan belas informan yang tidak bersedia disebutkan indentitasnya namun tetap bersedia memberikan jawaban ataupun mengisi koesioner dengan rincian pada tabel5.2 diatas. Koesioner yang peneliti persiapkan berisi pertanyaan tentang 
hal yang berhubungan dengan perbankan syariah di kecamatan dengan lima alternatif pilihan jawaban yaitu $\mathrm{SS}=$ Sangat Setuju, $\mathrm{S}=$ Setuju, $\mathrm{N}=$ Netral, $\mathrm{TS}=$ Tidak Setuju, dan STS = Sangat Tidak Setuju. Hasil pengumpulan data dengan media ini hasil perhitungannya dapat dilihat pada lampiran, sedangkan ringkasan hasil perhitungan dari jawaban kuesioner tersebut adalah sebagai berikut :

1) Dari pertanyaan tentang bagaimana pendapat anda tentang adanya perbankan syariah diperoeleh jawaban :
1) Sangat Setuju
: $90 \%$
2) Setuju
$: 10 \%$
3) Netral
$: 0 \%$
4) Tidak Setuju
$: 0 \%$
5) Sangat Tidak Setuju :0\%

2) Jawaban pertanyaan tentang bagiamana pula tanggapan anda tentang adanya pengembangan perbangkan syariah, diperoleh jawaban :
1) Sangat Setuju
$: 80 \%$
2) Setuju
$: 20 \%$
3) Netral
$: 0 \%$
4) Tidak Setuju
$: 0 \%$
5) Sangat Tidak Setuju : :0\%

\section{KESIMPULAN}

Dari pembahasan permasalahan di atas, dapat disimpulkan bahwa persepsi masyarakat santri di pondok Genggong baik yang merupakan nasabah maupun yang bukan nasabah bank syariah, ditinjau dari pendekatan budaya, sosial, pribadi dan psikologis, adalah positif terhadap bank syariah. Perbedaan yang terdapat pada kelompok masyarakat santri nasabah dan non nasabah adalah pada sikap atau pilihan mereka untuk memilih atau tidak memilih bank syariah

Pendekatan emosional dan rasional terhadap masyarakat santri dapat dilakukan secara bersama-sama dengan persyaratan:

1) Bank syariah harus dapat membuktikan dan meyakinkan bahwa produk yang 
dihasilkan benar-benar sesuai dengan syariah Islam; Pendekatan dilakukan dengan cara yang tepat, yaitu melalui pendekatan kepada ulama atau kyai yang menjadi panutan di wilayah tersebut.

2) Bank syariah dapat masuk pada kantong-kantong pesantren dan menjalin kerjasama dengan pesantren, karena faktor persepsi positif atas bank syariah serta jawaban responden atas alasan tidak menggunakan bank syariah adalah karena faktor tidak adanya bank syariah di daerah tersebut.

3) Penempatan Sumber Daya Insani (SDI) yang memahami transaksi bermuamalah yang sesuai syariah. SDI pada hakekatnya adalah pihak yang melaksanakan akad agar tidak keluar dari ketentuan syariah.

4) Dalam pendekatan kepada masyarakat santri yang telah menggunakan lembaga keuangan lain yang juga telah sesuai dengan syariah.

\section{DAFTAR PUSTAKA}

Adi Sasmita, Rahardjo, 2010, Pembangunan Kawasan dan Tata Ruang, Yogyakarta, Graha Ilmu.

Azwar.S, 2005, Sikap Manusia, Teori dan Pengukurannya, Jakarta, Pustaka Pelajar.

Fisher, R.C. 2006. State and Local Public Finance. New York, Irwin.

Klenow, and Peter, J., 2004. Externalities and Growth, dalam Phillipe Aghion dan Steven Durlauf, Handbook of Economic Growth. Amsterdam: North Holland Press.

Lukman Hakim, 2008, Dampak Ekologi, Ekonomi, Sosial dan Politik Dari Kebijakan Pertambangan di Hutan Lindung Tumpang Pitu Kabupaten Banyuwangi, Tesis Pasca Sarjana Universitas Jember.

Pakpahan, 1990, Menarik Pelajaran Dari Kedungombo, Forum Adil Sejahtera.

Schmid,A, 1987 Property, Power, and Public Choice, An Inquiry into Law and Economic, Praeger, New York, p.142-145

Fachruddin Fahmy, 2009, Persepsi Masyarakat Terhadap Pembukaan Pertambangan Emas di Hutan Batang Toru Kabupaten Tapanuli Selatan, Medan, Fak. Kehutanan Universitas Sumatera Utara. 
Rosen,H.S, 1988, Public Finance, Second Edition, Washington,ToppanCo.Ltd Verhoef, E.T

Michael Huberman, Matthew B. Miles, 2002, Qualitative Researcher's Companion, Sage Publications - International Educational Dan Professional Publisher, Thousand Oaks, London

John M. Ivancevich,Robert Konopaske,Michael T. Matteson, 2008, Perilaku dan Manajemen Organisasi (Jilid 1), Penerbit Erlangga, Jakarta id.wikipedia.org/wiki/Pesantren_Zainul_Hasan_Genggong Undang-Undang No 21 tahun 2008 tentang Perbankan Syariah www.bi.go.id. 